\title{
Ambiguous Signs, an Anonymous Character, Unanswerable Riddles: The Role of the Unknown in Johannine Epistemology
}

\author{
HAROLD W. ATTRIDGE \\ Yale Divinity School, 409 Prospect St, New Haven, CT 06511, USA. Email: harold. \\ attridge@yale.edu
}

\begin{abstract}
While the Gospel of John makes some forceful and explicit claims about the identity of Jesus and the character of his mission, it also invites readers into a deepened appreciation of its claims. Part of its strategy for doing so is to exploit ambiguity and to point to what the readers do not know. The article explores three examples of this pedagogical strategy: the deliberately hidden identity of the Beloved Disciple; the initial deeds of Jesus, labelled 'signs', which, however, do not in any direct and obvious way 'signify' anything, as the later works do; and the question debated by the crowds in Jerusalem, of where Jesus is from. In each case recognition of the unknown can be the first step towards discovering Truth.
\end{abstract}

Keywords: signs, Beloved Disciple, hidden Messiah, riddles, epistemology, Cana, Bethlehem, Nazorean

Jesus in the Fourth Gospel famously declares to his Judaean interlocutors that his mission is to provide to his disciples the 'truth' that will 'set them free' (8.32). Equally familiar is his declaration to Pilate that he came into the world for one purpose, to bear witness to the truth (18.37). The Fourth Gospel thus tells a tale of gnosis, not in the sense in which Gnostics of the second century would use the term, but yet in a profound and encompassing way. Many interpreters of the Gospel have worked diligently to unpack the content of that liberating Truth and most would no doubt have some version of the summary found in 1 John 4.16, that God is love and those who abide in love abide in God and God in them. That core claim would be surrounded by other affirmations, about the person of Jesus, the role of the Spirit, the implications of a commitment to live in love, etc. All of this Johannine teaching constitutes the positive truth to which the lapidary claims of Jesus to the Judaeans and to Pilate point. That familiar territory is not what I would like to explore in this article. Instead I would like to focus on an element of the process of coming to acquire knowledge of the truth in the framework provided by the gospel. 
I choose the word 'process' deliberately because the gospel assumes that the way to liberating knowledge involves one. The initial claim about liberating truth in 8.31 points in that direction. There Jesus says, 'If you continue [so the NRSV, we might prefer to translate $\mu \varepsilon i ́ v \eta \tau$ as "abide"] in my word, you are truly my disciples; and you will know the truth.' 'Continuing' or 'abiding' involves moments of recognition, the anagnoresis of a Mary Magdalene or Doubting Thomas. ${ }^{1}$ But 'abiding in the word' also involves preparation for that point of dramatic encounter, and that process involves encounters with what is not known or what cannot be known in a simple way.

This feature of the gospel is part of the sophisticated conceptual fabric interwoven in the dramatic narrative, a fabric that many scholars such as George van Kooten ${ }^{2}$ and Troels Engberg-Pedersen ${ }^{3}$ have insightfully explored. This conceptual fabric concerns not only ontology, but also religious epistemology. Engberg-Pedersen offers some important insights into this dimension of the gospel, ${ }^{4}$ as does Jason Sturdevant's work on the pedagogical functions of the Logos. ${ }^{5}$ But more can be said about the role of the unknown and indefinite in the pedagogical process. This process is reflected in what commentators have identified as the gospel's 'riddles', ${ }^{6}$ provocative statements in Jesus' conversation, ${ }^{7}$ elements of Johannine

1 See K. B. Larsen, Recognizing the Stranger: Recognition Scenes in the Gospel of John (BIS 93; Leiden: Brill, 2008).

2 G. van Kooten, 'The “True Light Which Enlightens Everyone” (John 1:9): John, Genesis, the Platonic Notion of the "True, Noetic Light", and the Allegory of the Cave in Plato's Republic', The Creation of Heaven and Earth: Re-Interpretations of Genesis in the Context of Judaism, Ancient Philosophy, Christianity, and Modern Physics (ed. G. van Kooten; Leiden: Brill, 2005) 149-94.

3 T. Engberg-Pedersen, 'Logos and Pneuma in the Fourth Gospel', Greco-Roman Culture and the New Testament: Studies Commemorating the Centennial of the Pontifical Biblical Institute (ed. D. Edward A. and F. E. Brenk; NovTSup 143; Leiden/Boston: Brill, 2012) 27-48 and idem, John and Philosophy: A New Reading of the Fourth Gospel (Oxford: Oxford University Press, 2017), and the essays in T. Rasimus, T. Engberg-Pedersen and I. Dunderberg, eds., Stoicism in Early Christianity (Peabody, MA: Hendrickson, 2010).

4 Engberg-Pedersen, John and Philosophy, 177-202.

5 J. S. Sturdevant, 'Incarnation as Psychagogy: The Purpose of the Word's Descent in John's Gospel', NovT 56 (2014) 24-44 and idem, The Adaptable Jesus of the Fourth Gospel: The Pedagogy of the Logos (NovTSup 162; Leiden/Boston: Brill, 2015). Cf. also J. C. Tam, Apprehension of Jesus in the Gospel of John (WUNT 399; Tübingen: Mohr Siebeck, 2015).

6 T. Thatcher, Jesus the Riddler: The Power of Ambiguity in the Gospels (Louisville, KY: Westminster John Knox, 2006); P. Anderson, The Riddles of the Fourth Gospel (Minneapolis: Fortress, 2011).

7 See e.g. F. Back, 'Die rätselhaften “Antworten” Jesu: Zum Thema des Nikodemusgesprächs (Joh 3,1-21)', EvT 73 (2013) 178-89; J. G. van der Watt, 'John 1:1 - a "Riddle"? Grammar and Syntax Considered', The Prologue of the Gospel of John: Its Literary, Theological, and Philosophical Contexts. Papers read at the Colloquium Ioanneum 2013 (ed. J. G. van der Watt, R. A. Culpepper and U. Schnelle; WUNT 359; Tübingen: Mohr Siebeck, 2016) 57-78. 
characterisation, ${ }^{8}$ or tensions or apparent contradictions in the conceptual affirmations of the text. ${ }^{9}$ As Clement of Alexandria noted in the second century, riddles entice and provoke, which is what the gospel does in so many different ways. ${ }^{10}$ Confrontation with the unknown is also a part of the overall strategy. This article will explore three cases in which the unknown or unknowable plays a role.

\section{The Unknown Witness}

In an earlier essay ${ }^{11}$ I explored the function of an unknown element in the gospel, the identity of the character defined as a major eyewitness to the life, death and resurrection of Jesus. In brief: the final epilogue (21.24) to the gospel identifies the disciple whom Jesus loved as the one who has given written testimony to what Jesus did and said and his testimony is validated by the authorial 'we'. The detail about the witness to the piercing of Jesus' side makes a similar claim about the truth of his testimony (19.35). The most likely character to play that testimonial role is the Beloved Disciple who stood by the cross with Jesus's mother (19.26). The gospel's account thus claims to be based on an eyewitness, but unlike the witnesses encountered in legal circumstances, signing wills or contracts, this eyewitness cannot be definitively identified. Lack of proof has not prevented readers from trying to make an identification. As James Charlesworth's comprehensive survey documents, virtually every named character in the gospel, and many named elsewhere, have been proposed as the one whom Jesus loved. ${ }^{12}$ Yet the very fact that for almost 1,900 years people have been making the effort should give us pause.

Various explanations might account for such futility. It could be that the original readers knew the identity of the Beloved Disciple and he did not need to be named. Or it could be that the evangelist (or evangelists, if there were multiple authors), writing for a wider audience, deliberately kept the identity unknown, in order to do precisely what we can see readers constantly doing: rereading the

8 J.-M. Sevrin, 'The Nicodemus Enigma: The Characterization and Function of an Ambiguous Actor of the Fourth Gospel', Anti-Judaism and the Fourth Gospel: Papers of the Leuven colloquium, 2000 (ed. R. Bieringer, D. Pollefeyt and F. Vandecasteele-Vanneuville; Jewish and Christian Heritage Series 1; Assen: Van Gorcum, 2001) 357-69.

9 These tensions famously appear in the seemingly contradictory affirmations regarding Christology (10.30 vs 14.28) and eschatology (5.25-9 or $11.23-4$ vs $11.25-6$ ).

10 Clement of Alexandria, Strom. 5.4-9.

11 H. W. Attridge, 'The Restless Quest for the Beloved Disciple', Early Christian Voices: In Texts, Traditions, and Symbols. Essays in Honor of François Bovon (ed. D. H. Warren, A. G. Brock and D. W. Pao; BIS 66; Leiden: Brill, 2003) 71-80, repr. in idem, Essays on John and Hebrews (WUNT 264; Tübingen: Mohr Siebeck, 2010) 20-9.

12 J. H. Charlesworth, The Beloved Disciple: Whose Witness Validates the Gospel of John? (Valley Forge, PA: Trinity Press International, 1995). 
gospel, looking for the true eyewitness to the Word. If, in their quest, they are attentive to what they read, they should eventually come across One whose name they do know, and who tells them that he is THE witness to the Truth. That, of course, is the claim that Jesus makes to Pilate (19.35), one of the texts with which we began. If this process or rereading is correct, anxiety over the unknown can ultimately lead to a part of the knowledge that the gospel wants to convey.

One might attribute this interpretation of the rhetorical functions of the unnamed Beloved Disciple to the idle fantasy of a (post-)modern critic. It is certainly true that the Beloved Disciple has other functions in the text. ${ }^{13}$ Chief among these is his role as an ideal disciple, close to Jesus in his sacred meal, keeping watch at the crucifixion, and coming to belief at the sight of the empty tomb. As the adopted brother of Jesus he may also serve as an alternative to other 'brothers' of Jesus prominent in the early Christian movement. That a character can have more than one rhetorical function is certainly possible and, in the case of the Fourth Gospel, entirely likely, but these other functions do not preclude the possibility that the unidentified disciple is a deliberate literary 'hook'. What enhances the plausibility of this reading is that the 'hook' is not unique. The ill-defined and unknown work in similar ways in other aspects of the gospel.

\section{Ambiguous Signs ${ }^{14}$}

The initial conclusion to the Fourth Gospel (20.30-1) indicates that this is a text full of 'signs', written so that readers may 'believe'. Yet only two deeds of Jesus are formally designated as 'signs', the wine miracle at Cana (2.11) and the healing of the royal official's son (4.54). The other deeds or 'works' of Jesus in the first twelve chapters, including his 'cleansing' of the Temple and his miraculous healings, may count as signs, as do events in the last half of the gospel, despite the lack of the designation. The generic references to Jesus' wonders as 'signs' at 11.47 and 12.18 suggest as much.

13 For some recent attempts to understand the role of the figure, see R. Bauckham, 'The Beloved Disciple as Ideal Author', JSNT 49 (1993) 21-44; M. Theobald, 'Der Jünger, den Jesus liebte: Beobachtungen zum narrativen Konzept der johanneischen Redaktion', GeschichteTradition-Reflexion: Festschrift für Martin Hengel zum 7o. Geburtstag (ed. H. Cancik, H. Lichtenberger and P. Schäfer; 3 vols.; Tübingen: Mohr Siebeck, 1996) III.219-55; D. R. Beck, "'Whom Jesus Loved": Anonymity and Identity: Belief and Witness in the Fourth Gospel', Characters and Characterization in the Gospel of John (ed. C. W. Skinner; LNTS 461; London: Bloomsbury, 2013) 221-39.

14 A version of this portion of this article appeared as 'How Do Signs Signify (or Don't)', Anatomies of the Gospels and Early Christianities: Essays in Honor of R. Alan Culpepper (ed. E. S. Malbon, M. Parsons and P. N. Anderson; BIS; Leiden: Brill, 2018) 335-47. 
Exactly what constitutes a 'sign' has been a matter of considerable debate. ${ }^{15}$ At one level, and perhaps in a source document or tradition underlying the gospel, ${ }^{16}$ 'signs' may be construed simply as portents of eschatological significance, part of the dynamic duo of 'signs and wonders'. ${ }^{17}$ That pair could elsewhere characterise what Moses did in Egypt (Acts 7.36), what Jesus did in first-century Palestine (Acts 2.22), and what his disciples did in imitating him. ${ }^{18}$ Yet Jesus in the Fourth Gospel is critical of those whose faith rests on such wondrous signs (4.48). Moreover, the signs that he does throughout the gospel are never labelled with that well-worn combination of 'signs and wonders'. For the evangelist then, the 'signs' that Jesus does are probably not simple miraculous portents.

Among the many possible senses that $\sigma \eta \mu \varepsilon$ iov might have, ${ }^{19}$ it could refer to a 'standard' or a 'token' identifying its bearer. That seems to be the obvious sense of

15 Scholars who have wrestled with the significance of 'signs' include P. Riga, 'Signs of Glory: The Use of "Semeion” in St. John's Gospel', Int 17 (1963) 402-10; S. Hofbeck, Semeion: Die Bedeutung des 'Zeichens' im Johannesevangelium unter Berücksichtigung seiner Vorgeschichte (Münsterschwarzacher Studien 3; Münsterschwarzach: Vier Türme Verlag, 1970²); M. de Jonge, 'Signs and Works in the Fourth Gospel', Miscellanea Neotestamentica (ed. T. Baarda, A. F. J. Klijn and W. C. van Unnik; NovTSup 48; Leiden: Brill, 1978) 107-25; L. Morris, 'The Relation of the Signs and the Discourses in John', The New Testament Age: Essays in Honor of Bo Reicke (ed. W. C. Weinrich; Macon, GA: Mercer University Press, 1984) 363-72; M. M. Thompson, 'Signs and Faith in the Fourth Gospel', BBR 1 (1991) 89-108; A. Guida, 'From parabole to semeion: The Nuptial Imagery in Mark and John', Between Author and Audience in Mark: Narration, Characterization, Interpretation (Sheffield: Sheffield Phoenix, 2009) 10320; G. van Belle, 'The Resurrection Stories as Signs in the Fourth Gospel: R. Bultmann's Interpretation of the Resurrection Revisited', Resurrection of the Dead: Biblical Traditions in Dialogue (ed. G. von Oyen and T. Shepherd; Leuven/Paris/Walpole, MA: Peeters, 2013) 249-64.

16 On the 'signs source' as the origin of the equation of 'signs' and miracles, and the consequent

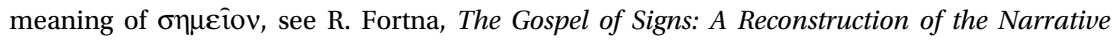
Source Underlying the Fourth Gospel (SNTSMS 11; Cambridge: Cambridge University Press, 1970) and idem, The Fourth Gospel and its Predecessor: From Narrative Source to Present Gospel (Studies in the New Testament and its World; Edinburgh: T. \& T. Clark/Philadelphia: Fortress, 1989); W. Nicol, The Semeia in the Fourth Gospel: Tradition and Redaction (NovTSup 32; Leiden: Brill, 1972). Most recently, U. C. von Wahlde, The Gospel and Letters of John (Eerdmans Critical Commentary; 3 vols.; Grand Rapids: Eerdmans, 2010) finds in the first of three editions of the gospel the distinctive use of 'signs' for 'miracles'. For criticism of the hypothesis: G. van Belle, The Signs Source in the Fourth Gospel: Historical Survey and Critical Evaluation of the Semeia Hypothesis (BETL 116; Leuven: Peeters, 1994) in general, and for particular cases, idem, 'The Meaning of $\sigma \eta \mu \varepsilon i \alpha$ in Jn 20,30-31', EThL 74 (1998) 300-25 and idem, 'The Signs of the Messiah in the Fourth Gospel: The Problem of a "Wonder-Working Messiah"', The Scriptures of Israel in Jewish and Christian Tradition: Essays in Honour of Maarten J. J. Menken (ed. B. J. Koet, S. Moyise and J. Verheyden; NovTSup 148; Leiden: Brill, 2013) 159-78.

17 Matt 24.24; Mark 13.22; Acts 2.19; 2 Thess 2.9.

18 Acts 2.43 ; 4.30; 5.12; 6.8; 14.1; 15.12; Rom 15.19; 1 Cor 12.12; Heb 2.4.

19 For basic lexical data, see K. Rengstorf, ' $\sigma \eta \mu \varepsilon i \hat{o v}$ ', TDNT VII (1971) 200-69. 
the second appearance of the word, shortly after the miracle at Cana. When Jesus throws the merchants and moneychangers out of the Temple (2.18), 'the Jews' ask him what $\sigma \eta \mu \varepsilon i o v$ he might show them 'that he does these things' (ö $\tau \tau \tau \alpha \hat{\tau} \tau \alpha$ $\pi$ orki $\zeta)$. The question seems to be asking for some symbol authorising Jesus' action. His response, promising the restoration of a destroyed sanctuary (voós), seems to suggest that a 'sign' is indeed a wondrous occurrence. Yet as so often in this ironic gospel, his interlocutors misunderstand Jesus' comment. They believe, quite naturally perhaps, that he is talking about the Temple, while the narrator notes that he is referring to his body (2.21), something that his disciples later creatively 'remembered' ${ }^{20}$ When it comes to understanding 'signs', misperceptions happen. Is there perhaps a misperception on the part of Jesus' interlocutors that the 'signs' that Jesus performs are simple 'tokens' of his status?

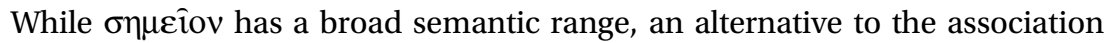
with the miraculous is the term's philosophical usage. ${ }^{21}$ Aristotle defined a

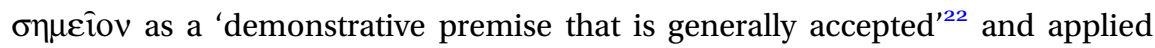
the term to the basis of plausible argument, as opposed to a certain proof. ${ }^{23}$ For Plato, the term can mean 'proof'. ${ }^{24}$ Epicurean philosophers of the Hellenistic period had a more positive notion, arguing for the invisible (atoms

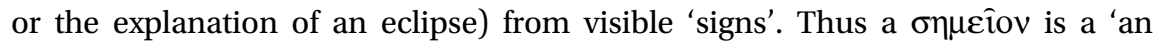
observable basis of inference to the unobserved or unobservable'. ${ }^{25}$ Stoics too used the notion, debating what kind of inference moved from the visible to the invisible. The academic Sceptic Sextus Empiricus, in arguing against inferences, discussed two kinds of sign. Some are what 'renew an object observed' ${ }^{26}$

20 For the creativity of memory, see especially J. Zumstein, Kreative Erinnerung: Relecture und Auslegung im Johannesevangelium (Zürich: Theologischer Verlag, 2004²).

21 For earlier treatments of possible philosophical connections, see R. Formesyn, 'Le sèmeion johannique et le sèmeion hellénistique', EThL 38 (1962) 856-94; P. Ciholas, 'The Socratic and Johannine Semeion as Divine Manifestation', PRSt 9 (1982) 251-65; R. Hirsch-Luipold,

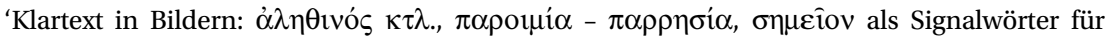
eine bildhafte Darstellungsform im Johannesevangelium', Imagery in the Gospel of John (ed. J. Frey, J. G. Van der Watt and R. Zimmermann; WUNT II/200; Tübingen: Mohr Siebeck, 2006) 61-102.

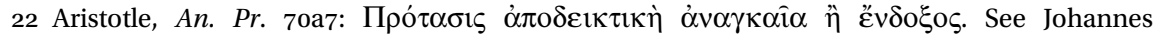
Brachtendorf, 'Semeion (Zeichen; lat.: signum)', in Wörterbuch der antiken Philosophie (ed. C. Horn and C. Rapp; Munich: Beck, 2008) 392-94.

23 See An. pr. 2.27; [Probl.] 701; Soph. elench. 167b9; Rhet. 1357a33, where enthymemes depend

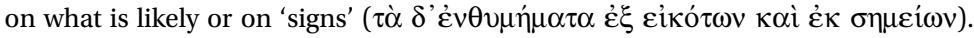

24 Plato, Gorg. 520e.

25 See LSJ s.v. II.3.b, citing Epicurus, Ep. 2 to Pythocles (apud Diogenes Laertius, Lives 10.97), where $\sigma \eta \mu \varepsilon i \hat{\alpha}$ are $\tau \grave{\alpha} \varphi \alpha$ ivó $\mu \varepsilon v \alpha$, which must be carefully observed and not dismissed by the strength of a theory, and Philodemus, Sign. 27.

26 Sextus Empiricus, Math. 8 (= Adv. log. 2). 143. The sign that recalls something is $\tau$ ò $\pi \rho$ ò $\varsigma$

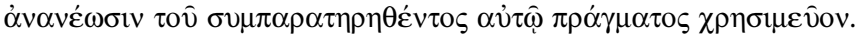


Others make the 'non-evident' 'evident'. ${ }^{27}$ They come in two forms, signs that stimulated recollection and signs that revealed something new. For some philosophers of the Hellenistic period 'signs', or at least some signs, are thus reminders or pointers that can disclose what is hidden, which is precisely what 'signs' usually do in the Fourth Gospel.

The suggestion that 'signs' have to do with signification in some technical sense should not be surprising. That the gospel might be interested in how 'signs' 'signify' anything is part of its pervasive epistemological concern. Like any signifiers, Johannine $\sigma \eta \mu \varepsilon i \alpha$ have a connotation, a sense that they convey, and a denotation, a reality to which they point, as was clearly the case with the misunderstood 'sign' at 2.18-22. For many of the gospel's 'signs', abundant indications within the text guide readers or hearers towards the realities to which they point. Elements of the narrative or accompanying discourses shape the ways in which 'signification' occurs. Often the signification is not univocal. Kaleidoscopic signs can have multiple senses and references. ${ }^{28}$ The healing of a paralytic on Shabbat, as the following defensive exchange makes clear, ${ }^{29}$ points to the reality of Jesus' equality with the Father, while it foreshadows the power of Jesus to effect resurrection. The multiplication of loaves and fish, as the Bread of Life homily ${ }^{30}$ indicates, points to the reality of Jesus, as the source of life, both through his teaching and through the 'flesh' and 'blood' that his followers must 'consume', however eating flesh and drinking blood are understood. ${ }^{31}$ The healing of a man born blind, in contrast with the spiritual

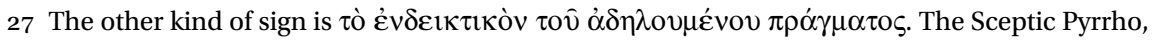
according to Diogenes Laertius, Lives 9.96, simply denied that there were either 'sensible' ( $\alpha i \sigma \theta \eta \tau o ́ v)$ or 'intelligible' (voךtóv) signs.

28 Signs thus resemble the gospel's striking images, Light, Life, Way, Truth, etc. See n. 22 above. 29 See H. W. Attridge, 'Argumentation in John 5', Rhetorical Argumentation in Biblical Texts (ed. A. Eriksson, T. H. Olbricht and W. Übelacker; Emory Studies in Early Christianity 8; Harrisburg, PA: Trinity Press International, 2002) 188-99, repr. in Essays on John and Hebrews (WUNT 264; Tübingen: Mohr Siebeck, 2010) 93-104.

30 So styled since P. Borgen, Bread from Heaven: An Exegetical Study of the Concept of Manna in the Gospel of John and the Writings of Philo (NovTSup 10; Leiden: Brill, 1965).

31 The two portions of the discourse have long generated speculation about the relationship between its symbolic elements. On the history of scholarship, see P. N. Anderson, The Christology of the Fourth Gospel: Its Unity and Disunity in the Light of John 6 (WUNT II/77; Tübingen: Mohr Siebeck, 1996; Eugene, OR: Cascade, 2010³). On the complex, but integrated, symbolism of the passage, see G. Richter, 'Zur Formgeschichte und literarischen Einheit von Joh 6,31-58', idem, Studien zum Johannesevangelium (ed. J. Hainz; BU 13; Regensburg: Pustet, 1977) 88-119; D. Swancutt, 'Hungers Assuaged by the Bread from Heaven: "Eating Jesus" as Isaian Call to Belief. The Confluence of Isaiah 55 and Psalm 78(77) in John 6:22-71', Early Christian Interpretation of the Scriptures of Israel: Investigations and Proposals (ed. C. A. Evans and J. A. Sanders; JSNTSup, 148; Sheffield: Sheffield Academic, 1997) 218-51; M. Labahn, Offenbarung in Zeichen und Wort: Untersuchungen zur Vorgeschichte von Joh 6,125a und seiner Rezeption in der Brotrede (WUNT II/117; Tübingen: Mohr Siebeck, 200o); T. 
'blindness' of the Pharisees (9.40-1), points to the reality of the opening of the mind's eye resulting from an encounter with Truth incarnate. ${ }^{32}$ The raising of Lazarus shows Jesus as Lord over life and death; foreshadowing his own resurrection, it offers a hope of new life here and now, in a relationship with Jesus. ${ }^{33}$ In all of these 'signs' the sense and the referent of the signified may be complex, but abundant indications in narrative and dialogue direct the reader to interpret how the 'signs' 'signify'.

What obtains for most of the gospel's signs, however, does not obtain in the case of the first two deeds explicitly labelled 'signs'. No subtle dialogue or suggestive motifs surround the wine miracle or the healing of the royal official's son to guide the reader into a process of reflection. Yet the absence of textual clues has not prevented interpreters from suggesting how these 'signs' 'signify'. Consider just the miracle at Cana.

Not guided by obvious textual prompts, readers have heard in this story echoes of scripture ${ }^{34}$ or found symbolic significance in its structure and its

Popp, Grammatik des Geistes: Literarische Kunst und theologische Konzeption in Johannes 3 und 6 (AzBiG 3; Leipzig: Evangelische Verlagsanstalt, 2001); J. Webster, Ingesting Jesus: Eating and Drinking in the Gospel of John (SBLABib 6; Atlanta: SBL, 2003); M. Stare, Durch ihn Leben: Die Lebensthematik in Joh 6 (NTA 49; Münster: Aschendorff, 2004); S. Hylen, Allusion and Meaning in John 6 (BZNW 137; Berlin and New York: de Gruyter, 2005); M. Warren, My Flesh Is Meat Indeed: A Non-Sacramental Reading of John 6 (Minneapolis: Fortress, 2015).

32 M. Gourgues, 'L'aveugle-né: du miracle au signe. Typologie des réactions à l'égard du Fils de l'homme', NRTh 104 (1982) 381-95; M. Labahn, “"Blinded by the Light”: Blindheit, sehen und Licht in Joh 9. Ein Spiel von Variation und Wiederholung durch Erzählung und Metapher', Repetitions and Variations in the Fourth Gospel: Style, Text, Interpretation (ed. G. van Belle, M. Labahn and P. Maritz; BETL 223; Leuven: Peeters, 2009) 453-509; J. Frey, 'Sehen oder Nicht-Sehen? (Die Heilung des blind Geborenen) - Joh 9,1-41', Kompendium der frühchristlichen Wundererzählungen, vol. I: Die Wunder Jesu (ed. R. Zimmermann; Gutersloh: Gütersloher Verlagshaus, 2013) 725-41.

33 M. Labahn, Jesus als Lebensspender: Untersuchungen zu einer Geschichte der johanneischen Tradition anhand ihrer Wundergeschichten (BZNW 98; Berlin/New York: de Gruyter, 1999) 378-465; W. E. Sproston North, The Lazarus Story within the Johannine Tradition (JSNTSup 212; Sheffield: Sheffield Academic, 2001); van Belle, 'The Resurrection Stories', 249-64; R. Zimmerman, 'Vorbild im Sterben und Leben (Die Auferweckung des Lazarus) - Joh 11,112,11', Kompendium, 742-63.

34 R. D. Aus, 'The Wedding Feast at Cana (John 2:1-11), and Ahasuerus' Wedding Feast in Judaic Traditions on Esther 1', idem, Water into Wine and the Beheading of John the Baptist: Early Jewish-Christian Interpretation of Esther 1 in John 2:1-11 and Mark 6:17-29 (Brown Judaic Studies 150; Atlanta: Scholars, 1988) 1-37; E. Little, Echoes of the Old Testament in the Wine of Cana in Galilee (John 2:1-11) and the Multiplication of the Loaves and Fish (John 6:1-15): Towards an Appreciation (CahRB 41; Paris: Gabalda, 1998). 
many curious details ${ }^{35}$ including Jesus' relationship with his mother, the 'stone jars', and the apparent abundance of wine. How to make sense of those details has been hotly debated. As Barnabas Lindars noted, 'the possibilities are endless' ${ }^{36}$ For Lindars himself the 'nucleus' of the story is the saying in v. 10, 'You have kept the good wine until now', ${ }^{37}$ a pointer to the newness of the revelation that Jesus brings. Or one could hear in the story a polemical edge. Here the stone jars play a role, since, as the combination of the Mishnah and archaeological evidence of first-century Galilee suggests, they involve halakhic concerns for purity. ${ }^{38}$ Lurking in the background of the stone jars could be the old wineskins of Mark 2.22 and parallels. ${ }^{39}$ Yet the setting of the Synoptic saying ${ }^{40}$ clearly frames it within the context of controversy with Pharisees. The Fourth Gospel lacks such a setting. An intertextual allusion here construing the 'sign' as a pointer to the supersession of old halakah is possible, but the story itself lacks any clear indication of such concern. ${ }^{41}$

35 M. Christudas, The Symbolism of the Miracle of the Wine at Cana (Jn 2:1-11): An ExegeticoTheological Study (Rome: Pontificia Studiorum Universitas a Sancto Thoma Aquinate, 2004); A. Wucherpfennig, 'Die Hochzeit zu Kana: Erzählperspektive und symbolische Bedeutung', TheoPhil 79 (2004) 321-38.

36 B. Lindars, The Gospel of John (New Century Bible; London: Oliphants, 1972; repr. Greenwood, SC: Attic, 1977) 123.

37 Lindars, Gospel of John, 126 follows R. Schnackenburg, The Gospel according to St. John (trans. Kevin Smyth; 3 vols.; London: Burns \& Oates/New York: Crossroad, 1968-82), who identifies the verse as the 'essence' of the story.

38 R. Deines, Jüdische Steingefässe und pharisäische Frömmigkeit: Eine archäologisch-historischer Beitrag zum Verständnis von Joh 2,6 und der jüdischen Reinheitshalacha zur Zeit Jesu (WUNT II/52; Tübingen: Mohr Siebeck, 1993); J. L. Reed, 'Stone Vessels and Gospel Texts: Purity and Socio-Oeconomics in John 2', Zeichen aus Text und Stein: Auf dem Weg zu einer Archäologie des Neuen Testaments (ed. S. Alkier and J. Zangenberg; TANZ 42; Tübingen: Mohr Siebeck, 2007) 381-401.

39 Matt 9.17; Luke 5.37. Such an allusion would be an example of the kind of complex intertextuality highlighted by H. Thyen, 'Johannes und die Synoptiker: Auf der Suche nach einem neuen Paradigma zur Beschreibung ihrer Beziehungen anhand von Beobachtungen an Passions-und Ostererzählungen', John and the Synoptics (ed. A. Denaux; BETL 101; Leuven: Leuven University Press, 1992) 81-108, and perhaps an example of a 'relecture' of Synoptic tradition. For such a version of intertextuality, see J. Zumstein, 'Ein gewachsenes Evangelium: Der Relecture-Prozess bei Johannes', Johannesevangelium - Mitte oder Rand des Kanons? Neue Standortbestimmungen (ed. T. Söding, K. Berger and J. Frey; QD 203; Freiburg/Basle/Vienna: Herder, 2001) 9-37 and idem, Évangile selon St. Jean (2 vols.; Geneva: Labor et Fides, 2014) 2007-14) I.31.

40 Matt 9.14; Mark 2.18; Luke 5.33.

41 Another attempt to find a polemical dimension to the story is A. Geyser, 'The semeion at Cana of Galilee', Studies in John: Presented to Dr. J. N. Sevenster on the Occasion of his Seventieth Birthday (Leiden: Brill, 1970) 12-21, who implausibly sees it as directed against the purification ritual of John the Baptist. 
Other interpreters focus on the abundance of the wine that Jesus produces, often deemed excessive, ${ }^{42}$ although even that judgement has been challenged by evidence of domestic facilities for storing large quantities of wine. ${ }^{43}$ Whether the wine is excessive may be debated; that it is abundant for the needs of the wedding seems sure. Some find in this oenological abundance an allusion to ${ }^{44}$ or perhaps polemic against ${ }^{45}$ a rival cultic tradition, the worship of Dionysus. Such an interpretation usually depends on a theory of the role of Dionysus in the larger religio-historical context, ${ }^{46}$ and a source critical analysis of the gospel. ${ }^{47}$ Since it is difficult to construe the whole gospel in its current form as an anti-Dionysiac tract, the wine miracle is located at an early stage of the gospel's development. But if that is where the 'sign' resides, does it have any significance for the constellation of signs in the gospel's mature form? Ancient stories of wine miracles may lie in the background of John 2, but that the story in its current form engages with them in an effort to convey some (anti-Dionysiac) sense or point to some rival (Dionysiac) referent is dubious.

Another option that the 'sign' of abundant wine might evoke is the banquet of the messianic or eschatological age ${ }^{48}$ described in Isa 25.6-10. The 'glory' that the disciples glimpse in this event (2.11) is a beam of light from that splendid reality now dawning. The event as a 'sign' would point to that reality and convey

42 So M. Dibelius, Die Formgeschichte des Evangeliums (Tübingen: Mohr Siebeck, 1959³) 98-9; S. Petersen, 'Wein im Überfluss (Die Hochzeit zu Kana) - Joh 2,11', Die Wunder Jesu (Gutersloh: Gütersloher Verlagshaus, 2013) 669-80.

43 See H. Förster, 'Die Perikope von der Hochzeit zu Kana (Joh 2:1-11) im Kontext der Spätantike', NovT 55 (2013) 103-26 and idem, 'Die johanneischen Zeichen und Joh 2:11 als möglicher hermeneutischer Schlüssel', NovT 56 (2014) 1-23.

44 E. Linnemann, 'Die Hochzeit zu Kana und Dionysus', NTS 20 (1974) 408-18; M. Hengel, 'The Interpretation of the Wine Miracle at Cana: John 2:1-11', The Glory of Christ in the New Testament: Studies in Christology in Memory of George Bradford Caird (ed. L. D. Hurst and N. T. Wright; Oxford: Clarendon, 1987) 83-112, repr. as 'The Dionysiac Messiah', M. Hengel, Studies in Early Christology (Edinburgh: Clark, 1995).

45 Labahn, Lebensspender, 120-67, for a balanced review; P. Wick, 'Jesus gegen Dionysos? Ein Beitrag zur Kontextualisierung des Johannesevangeliums', Bib 85 (2004) 179-98; W. Eisele, 'Jesus und Dionysos: Göttliche Konkurrenz bei der Hochzeit zu Kana (Joh 2,1-11)', ZNW 100 (2009) 1-28.

46 There is considerable evidence for interest in Dionysus in the first century. On the importance of Euripides' Bacchae in the period, see now C. J. P. Friesen, Reading Dionysus: Euripides' Bacchae and the Contestations of Greeks, Jews, Romans, Christians (STAC 95; Tübingen: Mohr Siebeck, 2015). On Dionysiac imagery in Palestine and reactions to it, see also J. M. Scott, Bacchius Judaeus: A Denarius Commemorating Pompey's Victory over Judaea (NTOA/ StUNT; Göttingen: Vandenhoeck \& Ruprecht, 2015).

47 See D. R. MacDonald, The Dionysian Gospel: The Fourth Gospel and Euripides (Minneapolis: Fortress, 2017).

48 M. M. Thompson, John: A Commentary (NTL; Louisville, KY: Westminster John Knox, 2015) 6o: 'The sign done at Cana bears witness to Jesus as the one who brings the rich fullness of the messianic age.' 
something of its promised joy. Yet as such a sign this too is imperfect, since Jesus and his disciples here do not eat, drink or make merry. Jesus is not the 'drunkard and glutton' he is accused of being in the Synoptics ${ }^{49}$ and he does not recline at table with publicans and sinners, ${ }^{50}$ actions that in Matthew (21.31-2) hail the inbreaking Kingdom. At Cana Jesus transforms water to wine and that's it.

The relationship to Jesus' mother may be a sign of something. ${ }^{51}$ Some find the story to symbolise the relationship between the Johannine community and its

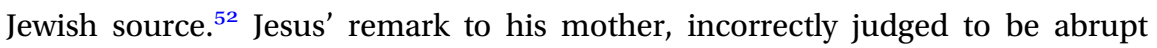
(2.4), indicates the Johannine community's distance from its source. Other details can be integrated into this symbolism. Thus the creation of the abundant new wine indicates the new reality that Jesus delivers. Yet other interpretations build on social science paradigms ${ }^{53}$ or focus on the practices of the community that read the gospel, finding in the new wine an allusion to Christ's Passion or to the 'blood' which the disciples must drink (John 6.53).

The fact that the Cana story recounts a wedding is potentially significant, ${ }^{54}$ particularly if this sign is read against the background of the Synoptic Gospels, where Jesus is often not very family-friendly. ${ }^{55}$ Jesus' aid to a potentially embarrassed bridal couple would seem to support the institution. Yet the story does not explicitly endorse marriage. The story of the wedding banquet is the first of several passages that will involve hints of erotic attraction that could be tied to the theme of Jesus as bridegroom. Such touches appear in the encounter of Jesus with the Samaritan woman (ch. 4), ${ }^{56}$ in the Last Supper vignettes of Jesus and the beloved disciple (ch. 13), ${ }^{57}$ and in the encounter with Mary Magdalene

49 Matt 11.19; Luke 7.34.

50 Matt 9.10; 11.19; Mark 2.15; Luke 5.29; 7.34; 15.1.

51 J. Lieu, 'The Mother of God in the Fourth Gospel', JBL 117 (1998) 61-77.

52 L. M. Bechtel, 'A Symbolic Level of Meaning: John 2.1-11 (The Marriage in Cana)', A Feminist Companion to the Hebrew Bible in the New Testament (ed. A. Brenner; Feminist Companion to the Bible 10; Sheffield: Sheffield Academic, 1996) 241-55.

53 R. H. Williams, 'The Mother of Jesus at Cana: A Social-Science Interpretation of John 2:1-12', CBQ 59 (1997) 679-92.

54 R. Zimmermann, Geschlechtermetaphorik und Gottesverhältnis: Traditionsgeschichte und Theologie eines Bildfelds in Urchristentum und antiker Umwelt (WUNT 2; Tübingen: Mohr Siebeck, 2001) 230-40.

55 While the Jesus of the Synoptics famously forbids divorce (Matt 5.32; 19.3-9; Mark 10.2-12; Luke 16.18), some sayings challenge excessive family loyalty (Matt 10.37). The Lukan (Luke 14.26) version, with its call to 'hate' father and mother and siblings, is especially striking.

56 See H. W. Attridge, 'The Samaritan Woman: A Woman Transformed', Character Studies in the Fourth Gospel: Literary Approaches to Sixty-Seven Figures in John (ed. S. A. Hunt, D. F. Tolmie and R. Zimmermann; WUNT 314; Tübingen: Mohr Siebeck, 2013) 268-81.

57 See H. W. Attridge, 'Plato, Plutarch, and John: Three Symposia about Love', Beyond the Gnostic Gospels (ed. E. Iricinschi, L. Jennott, N. Denzey Lewis and P. Townsend; STAC 82; Tübingen: Mohr Siebeck, 2013) 367-78. 
(ch. 20). ${ }^{58}$ In these stories too the transformative power of encounter with Jesus is at work, rendering incipient erotic attachment into service of the gospel.

The 'bridegroom' saying uttered by John the Baptiser at 3.29 may support the possibility that the Cana story evokes marital symbolism. John's recognition of Jesus as the 'groom', in whose voice the 'friend of the groom' delights, might encourage a reader to return to the mysterious first sign and understand Jesus in its light, a 'bridegroom' who does not marry, but who provides for abundant festivity. But it is significant that this hint comes well after the Cana story itself.

How do we evaluate all these options? And why would the storyteller interested in the symbolism or the 'sign' value of Jesus' deeds leave such ambiguity? While many options have something attractive about them, none is completely satisfactory. Objections or doubts can easily be raised to each. Perhaps this fact of the history of interpretation should be taken into account as we struggle with the potential meaning of the 'sign'.

The designation of the miracle at Cana as a 'sign', while perhaps rooted in traditions of labelling miraculous deeds as 'signs and wonders', functions as do the other 'riddles' of the gospel. The many tantalising touches of the brief story hint at possible ways in which this sign might signify, but none of those clues provides enough evidence to identify securely either the sense or the referent of the sign. A first-time reader or hearer might quickly skip over this fact, perhaps construing 'sign' in a simpler fashion, but once she has a taste of how other signs 'signify', she may return, as so many readers have in fact done, to probe further. The probing has yielded some intriguing results, but its major result is to engage the reader to explore the significance of all the 'signs'.

Furthermore, once the recurrent reader comes to the next encounter with the language of 'sign', in the question by 'the Jews' at 2.18 after the Temple event, she will appreciate all the more the irony of that exchange. Those who seek 'signs and wonders' to ground and authenticate their reaction to Jesus miss the point of what they have encountered. The action of Jesus, in the creative memory of his disciples, ${ }^{59}$ referred not to the Temple made of stone, but to the place(s) where He dwells, and it conveyed the message that there is no place in that dwelling for commercial exploitation.

In short, the 'signs' that Jesus offers perform an educative function. Their studied polyvalence, or in the case of the initial signs, their pronounced and probably deliberate ambiguity, engages the reader, provoking reflection and stimulating a deepening encounter with the Word embedded both in flesh and in the

58 See H. W. Attridge, 'Don't Be Touching Me: Recent Feminist Scholarship on Mary Magdalene', A Feminist Companion to John (ed. A.-J. Levine; 2 vols.; Cleveland: Pilgrim, 2003) II.140-66, repr. in idem, Essays on John and Hebrews (WUNT 264; Tübingen: Mohr Siebeck, 2010) 137-59.

59 For the notion of 'creative memory' as a central feature of the gospel, see Zumstein, Kreative Erinnerung. 
evangelist's words. Their unknowability provokes a quest to discover the hidden Truth.

\section{Origins Unknown ${ }^{60}$}

The identity of the Beloved Disciple and the ambiguity of potentially significant 'signs' are devices that have in fact stimulated engagement with the gospel. Both rely on what is not made known in the text and have produced various quests for the gospel's liberating truth. Yet another similar device is rooted in the fact that many episodes in the gospel portray scenes of ignorance on the part of characters. Dramatic irony, familiar to all recent readers of the gospel, ${ }^{61}$ is involved in many of these stories. One case, however, is particularly interesting because of its subtle, unstable irony, addressing knowledge about Jesus that many readers probably thought they had. The gospel challenges that presumed knowledge, much in the way that a Socratic dialogue or a Sceptic's elenchus would do.

The issue is where Jesus was from. Before examining John's treatment of the theme, it is useful to recall the different testimonies in other early Christian sources.

Mark's Jesus is from Nazareth (Mark 1.9) and Mark regularly labels him a Nazarene, ${ }^{62}$ which might have some esoteric meaning, but most likely simply means an inhabitant of the Galilean town. ${ }^{63}$ That town was then his 'native place' ( $\pi \alpha \tau \rho$ i $\varsigma$, Mark 6.1), where his nameless father, his mother Mary and his brothers and sisters lived (Mark 6.3).

Matthew and Luke supplement Mark with the name of the father, at least the earthly father of Jesus, Joseph. ${ }^{64}$ They also provide an additional report about his birthplace, his $\pi \alpha \tau \rho i ́ \varsigma$ in a very specific sense. It was not Nazareth, but, of course, Bethlehem, which according to Matt 2.6 fulfils the prophecy of Mic 5.1, 3. Luke $(2.4,15)$, on the other hand, sees the birth of Jesus fulfilling not prophecy but typology: the city of David is where shepherds appropriately come to honour their

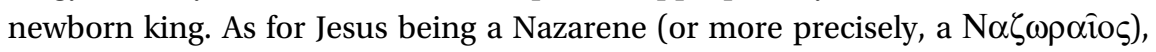

60 A version of the argument in this section of the article will appear as 'Some Methodological Considerations Regarding John, Jesus and History', Jesus Research: The Gospel of John in Historical Inquiry (ed. J. H. Charlesworth; London: T\&T Clark, forthcoming).

61 See e.g. P. D. Duke, Irony in the Fourth Gospel (Atlanta: John Knox, 1985) and R. A. Culpepper, 'Reading Johannine Irony', Exploring the Gospel of John: In Honor of D. Moody Smith (ed. R. A. Culpepper and C. C. Black; Louisville, KY: Westminster John Knox, 1996) 193-207; T. Nicklas, 'Die Prophetie des Kaiaphas: Im Netz johanneische Ironie', NTS 46 (2000) 589-94.

62 Mark $1.24 ; 10.47 ; 14.67 ; 16.6$.

63 See A. Yarbro Collins, Mark: A Commentary (Hermeneia; Minneapolis: Fortress, 2007) 147-8. 64 Matt 1.16, 18-20, 24; 2.13, 18; Luke 1.27; 2.4, 16; 3.23; 4.22. 
Matt 2.23 explains that label as the fulfilment of a mysterious scriptural prophecy, either Judges (Judg 13.5, 7; 16.17) or Isaiah (Isa 11.1). ${ }^{65}$ Gospel readers thus have two sets of witnesses, Mark, who knows nothing of Bethlehem, and Matthew and Luke, who may have invented or at least welcomed the tradition of Bethlehem as the birthplace of Jesus. ${ }^{66}$

John initially seems to follow in Mark's footsteps, with the addition of the name of Joseph. Among the first disciples of Jesus is Philip, from Bethsaida, who tells Nathanael that he has found the one of whom Moses and the prophets spoke, 'Jesus, the son of Joseph, from Nazareth' (John 1.45). Nathanael, of course, utters his famous sceptical putdown, 'What good indeed can come from Nazareth!': a stinging one-liner.

So, by the end of the gospel's first chapter readers seem to know where Jesus is from and what his father's name is. They will be reminded of these data in the words of the Ioudaioi in 6.42, and in the opinion of Pilate, who orders Jesus crucified as 'Jesus the Nazorean, King of the Jews' (19.19) ${ }^{67}$ But is this information, to put the question in Platonic terms, just $\delta$ ó $\xi \alpha$, 'opinion', rather than $\dot{\varepsilon} \pi 1 \sigma \tau \eta \dot{\mu}$, 'knowledge', or as John might put it, $\dot{\alpha} \lambda \hat{\eta} \theta \varepsilon 1 \alpha$, 'truth'? What we know is what Philip, the Ioudaioi and Pilate think about Jesus. Are Philip, the Ioudaioi and Pilate right to think so ${ }^{68}$

Nazareth does not serve as the setting for anything in the Fourth Gospel. Nearby Cana does, and Capernaum, a major venue in the Synoptics, makes cameo appearances. Jesus goes there after the wedding (2.12); there from a distance he cures an official's son (4.46), and there he delivers his Bread of Life homily, in a synagogue, where, the gospel tells us, he used to preach $(6.17,24$, 59). The Fourth Gospel knows of Jesus' activity in these parts of Galilee as well as in Judaea. Nazareth is nowhere in view.

The question of Jesus' native place resurfaces oddly at the end of chapter 4, after his successful visit to Samaria. The evangelist reports that Jesus left Samaria and went to Galilee, telling us he did so because he 'witnessed that a

65 On the problems with that verse, see U. Luz, Matthew 1-7: A Commentary (Hermeneia; Minneapolis: Fortress, 2007) 122-4.

66 On these traditions, see R. E. Brown, The Birth of the Messiah: From Gethsemane to the Grave (Garden City, NY: Doubleday, 1977) and F. Watson, Gospel Writing: A Canonical Perspective (Grand Rapids/Cambridge: Eerdmans, 2013) 156-68.

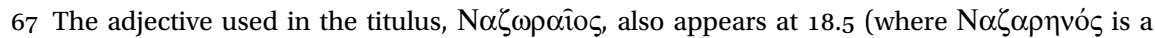
variant), 7 , on the lips of those who arrest Jesus. Matt 2.23 explains the term as a reference

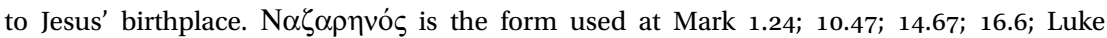
$4.34 ; 24.19$. It is possible that $\mathrm{N} \alpha \zeta \omega \rho \alpha \hat{i}$ ऽ does not primarily have a geographical reference. See BAGD s.v. b. In that case, its use in the later chapters of John may be a studied attempt to reinforce the point of the ironic play on Jesus' origins in ch. 7 .

68 The ways in which ancient narratives treat the perceptions of thoughts of characters is extensively explored by T. Smith, The Fourth Gospel and the Manufacture of Minds in Ancient Historiography, Biography, Romance, and Drama (BIS; Leiden: Brill, forthcoming 2019). 


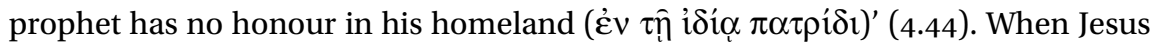
arrived, the Galileans received him, having seen all that he did in Jerusalem at the feast, a reference to the 'signs' in Jerusalem mentioned, but not reported, at 2.23.

The report at the end of chapter 4 leaves the reader, and most commentators, puzzled. ${ }^{69}$ Accepting the proverb about dishonoured prophets, Jesus leaves Samaria. Does that move, plus the fact of a warm welcome in Galilee, imply that Jesus is a Samaritan? Hardly, in view of his dialogue with the Samaritan woman (4.9), who identifies him as a Ioudaios. Moreover, he has just been warmly welcomed in Samaria, recognised as 'saviour of the world' (4.42). So the prophet without honour in his homeland has been warmly received in both Galilee and Samaria.

Perhaps Jesus is portrayed as testing the proverb. Knowing its truth, and having been recognised in Samaria, he realises that Samaria cannot be his true 'homeland'. So he tries Galilee, where he had family. That makes an interesting story, but it is not compatible with the gospel's portrait of Jesus. One who usually has preternatural knowledge should surely know what is his $\pi \alpha \tau \rho i c$. Another obvious option is that the proverb refers to Judaea, although readers have no reason to suspect that at this point, unless, of course, they had been reading Matthew and Luke. Yet even in Judaea, according to John 2.23, many believed in Jesus, having seen the signs he performed. So one could argue that at least at this point no region of ancient Israel would count as the 'homeland' where Jesus was not honoured.

Perhaps this puzzle is the result of inept redaction. Urban von Wahlde suggests that the proverb was inserted by a final editor, who intended to echo the saying in the Synoptics, but this editor, in von Wahlde's words, 'has not understood the original meaning of the material and the insertion results in confusion' ${ }^{70}$ Yet perhaps the proverb, with its questionable application, is connected to a larger theme.

The question of where Jesus is from resurfaces when Jesus teaches in the Temple at Succoth (7.14). After his initial response to hostile opposition (7.1418), Jesus presents a defence (7.19-24) of his Sabbath healing, reported in chapter 5. Jerusalemites react, noting the plot against him (7.26), reminding readers that Jesus is in hostile territory. The Jerusalemites, however, go on to wonder if the rulers (oi ö $\rho \chi 0 \vee \tau \varepsilon \varsigma$ ) know Jesus to be the Messiah (7.26). ${ }^{71}$ They

69 For source critical discussions, see M. Sabbe, 'John 4,46-54: Signs Source and/or Synoptic Gospels', EThL 60 (1984) 367-75, repr. in F. Neirynck, Evangelica II: 1982-91. Collected Essays (BETL 99; Leuven: Leuven University Press, 1991) 679-88; B. Lindars, 'Capernaum Revisited: Jn 4,46-53 and the Synoptics', The Four Gospels, 1992: Festschrift Frans Neirynck (ed F. van Segbroeck et al.; BETL 100; 3 vols.; Leuven: Leuven University Press/Peeters, 1992) 1985-2000.

70 Both citations are from von Wahlde, Gospel and Letters, II.203.

71 Is there a possible allusion to the notion articulated by Paul in 1 Cor 2.8 that none of the rulers

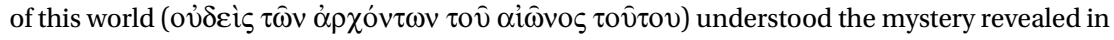
Christ? 
reject that possibility because they know where he is from, and one is not supposed to know where the Messiah is from (7.27). ${ }^{72}$ The crowd seems to know what Philip and Pilate know, that Jesus is apparently from Nazareth, though they do not make that clear. They also establish a principle that the Messiah's origins should be unknown. ${ }^{73}$

A brief digression on that principle is in order. John 7.27 suggests that some Jews thought that the Messiah's origins would be unknown. Enhancing that sense is the tone of the verse, which suggests that the notion is a truism, something so self-evident that no one would question it. ${ }^{74}$ Commentators have certainly taken it that way. Hartwig Thyen, following Walter Bauer, refers to the statement as a 'jüdische Schulmeinung' ${ }^{75}$ But was the notion of a hidden Messiah common in the 'schools'? Most commentators cite as evidence passages from 1 Enoch, 4 Ezra, 2 Baruch and Justin Martyr. ${ }^{76}$

Consider Justin. Trypho argues: 'If the Messiah has come to be and is present somewhere, he is unknown and does not even understand himself nor does he have any power, until Elijah comes, anoints him, and makes him known. ${ }^{77}$ Trypho's argument, as Raymond Brown suggests, may reflect speculation about

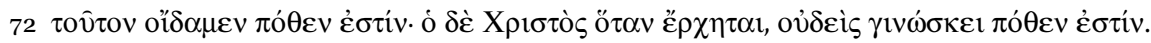
73 See C. Heil, 'Jesus aus Nazaret oder Bethlehem? Historische Tradition und ironischer Stil im Johannesevangelium', Im Geist und in der Wahrheit: Studien zum Johannesevangelium und zur Offenbarung des Johannes sowie andere Beiträge, FS M. Hasitschka (ed. K. Huber and B. Repschinski; NTA NF 52; Münster: Aschendorff, 2008) 109-30, esp. 115-19. Heil's article is in general the most useful treatment of the passages in John on the birth of Jesus, although the results of my analysis differ from his.

74 Compare the outrageous 'truisms' of Heb 6.16; 7.7.

75 H. Thyen, Das Johannesevangelium (HNT 6; Tübingen: Mohr Siebeck, 2005) 395, citing W. Bauer, Das Johannesevangelium erklärt (HKNT 6; Tübingen: Mohr Siebeck, $1933^{3}$ ) 36.

761 En. 48.6; 62.7; 4 Ezra 7.28; 13.26, 32, 51-2; 2 Bar. 29.3; 39.7; 72.2; and especially Justin, Dial. 8.4; 110.1. See C. K. Barrett, The Gospel according to St. John (Philadelphia: Westminster/ London: SPCK, 1978²) 322; R. E. Brown, The Gospel according to John (2 vols.; AB 29, 29A; Garden City, NY: Doubleday, 1966-70) I.53; B. Lindars, The Gospel of John (New Century Bible; London: Oliphant/Grand Rapids: Eerdmans, 1972) 293; F. Moloney, John (Sacra Pagina 4; Collegeville, MN: Liturgical Press, 1998) 248; M. Theobald, Das Evangelium des Johannes: Kapitel 1-12 (RNT; Regensburg: Friederich Pustet, 2009) 526; M. M. Thompson, John: A Commentary (The New Testament Library; Louisville, KY: Westminster John Knox, 2015) 172-3. Other texts occasionally cited do not really contain the motif of a hidden or unknown Messiah. They just do not specify a place of origin. These include Isa 7.14-17; Mal 3.1, a classic passage taken to refer to an eschatological prophet; Dan 7.13, the vision of the Son of Man, cited by Moloney. See also M. de Jonge, Jesus: Stranger from Heaven and Son of God. Jesus Christ and the Christians in Johannine Perspective (SBLSBS 11; Missoula, MT: Scholars, 1977) 77-116.

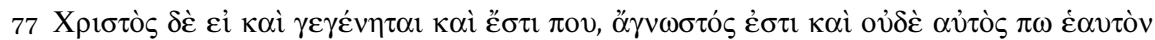

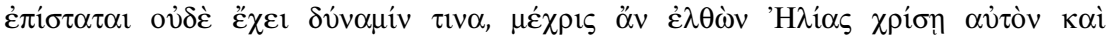

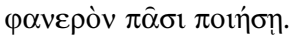


the Son of Man as a mysterious heavenly figure found in 1 Enoch and 4 Ezra. ${ }^{78}$ If Brown is correct, what the crowds are saying, that the Messiah's origins are unknown, is not exactly what would be in the 'schools' of the first century; it is a Johannine adaptation of a messianic expectation.

Some commentators connect Trypho's statement with the so-called 'hidden Messiah' motif of the Rabbis, ${ }^{79}$ citing b. Sanh. $97 \mathrm{a}-99 \mathrm{~b}$. Yet the stories in the Bavli are not about a messiah whose origin is unknown, nor a messiah hidden in heaven, but a human being who does not even know that he is the messiah. So, the Jerusalemites in the Fourth Gospel are not saying what Trypho said, nor are they articulating the kinds of doubts that the Bavli contains about the human ability to know when the Son of David will come. As some commentators recognise, the 'evangelist' is responsible for framing a motif that suits his narrative purpose; he is not simply recording Jewish tradition. ${ }^{80}$

So, let us return to the main issue, the quest for the 'native land' or 'fatherland' of Jesus. The conversation among Jesus' listeners in Jerusalem at John 7.26-7 establishes two things. The Judaeans think they know where Jesus is from and they certainly know that the place where the Messiah comes from will be a mystery.

Jesus' immediate response at 7.28 makes the basic Johannine position clear.

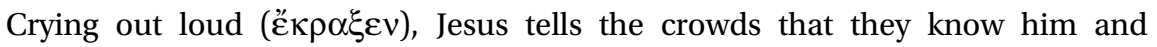

78 'This type of messianism [sc. what is suggested by John 7.27] is much closer to the hidden-Sonof-Man expectations of Enoch than to the standard Davidic expectations associated with Mic v 2, and may really represent a conflation of the two strains', Brown, Gospel, I.53. Theobald, Evangelium, 526 cites this as a possibility behind the verse, citing E. Sjöberg, Der verborgene Menschensohn in den Evangelien (Skrifter 53; Lund: Gleerup, 1955) 72-4 and K. Wengst, Bedrängte Gemeinde und verherrlichter Christus: Ein Versuch über das Johannes-Evangelium (München: Kaiser, 1990; $1992^{4}$ ) 113-15.

79 Brown, Gospel, I.53: He refers the reader to S. Mowinckel, He That Cometh: The Messiah Concept in the Old Testament and Later Judaism (Oxford: Blackwell, 1959; repr. Grand Rapids: Eerdmans, 2005) 304-08; Ethelbert Stauffer, 'Agnostos Christos', The Background of the New Testament and its Eschatology (ed. W. D. Davies and D. Daube; Cambridge: Cambridge University Press, 1956) 281-99.

80 Barrett suggests that John has 'theologized' or 'retheologized' a concept that had become 'secularized', whatever that means. He explains that the secret origin 'is, or should be, equivalent to the admission that all human judgement about it is, and is bound to be, inadequate', Barrett, Gospel, 322, citing R. H. Lightfoot, St. John's Gospel: A Commentary (Oxford: Clarendon, 1956) and R. Bultmann, The Gospel of John (Philadelphia: Westminster/Oxford: Blackwell, 1971; English trans. of Das Evangelium des Johannes (KEK; Göttingen: Vandenhoeck \& Ruprecht, 1941; with the supplement of 1966, repr. 1950-86) 296. For other opinions Thompson, John, 173: 'Jesus' point here is that while looking for his identity in terms of his parentage, or his origins, they miss the fact that he can only be known in relation to the God who sent him.' Zumstein, Évangile, I.172 cites the usual texts, and describes the hidden Messiah notion as 'une tradition relativement tardive dans le judaïsme antique'. He suggests that this might have been a point of debate between Johannine Christians and Jews. 


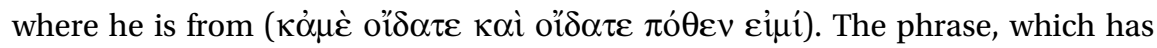
more than a hint of sarcasm, might be read as a question, 'So you know about me,

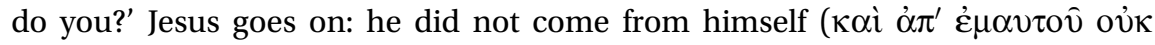
$\dot{\varepsilon} \lambda \dot{\eta} \lambda v \theta \alpha$ ). This remark too is laced with sarcasm. Who, apart perhaps from some supernal entities in gnostic cosmologies, 'come from themselves'? ${ }^{81}$ Finally Jesus says, the Father who sent him is true and of that Father the crowd is ignorant. ${ }^{82}$ In case his interlocutors did not get it the first time, Jesus restates the principle in v. 29 in positive terms: he knows the Father, he is from the Father, and it is the Father who sent him. ${ }^{83}$ This is familiar Johannine territory with claims frequently made. ${ }^{84}$ Unlike the hidden Messiah of Trypho or the Bavli, Jesus knows who he is and where he is from; his truest homeland is the Father's bosom. Of this origin the Jerusalemites remain ignorant.

At this point most readers savour the ironic twist in the encounter. The crowds claim to know where Jesus is from, but because they, like Nicodemus, the Samaritan woman and the well-fed disciples before them, are thinking only in earthly terms, they do not know what they think they know. The fact that they do not really know where the Messiah is from illustrates the truth of their proverbial principle, as shaped by the evangelist in v. $27 .{ }^{85}$ In their misperception of a theological claim, as in the case of the cynical Caiaphas (11.50), lurks what the evangelist takes to be a profound truth.

So far, so good, and so far so characteristic of the gospel, and it is hardly a controversial point that this gospel uses irony to make theological claims, but the story does not end at v. 29. The simple historical question remains open.

The account of Jesus in Jerusalem at the luminous Feast of Tabernacles continues. His enemies seek to seize him, but it is not yet time (7.30). Some locals believe in him; the Pharisees and high priests are worried (7.31-3). The suspense builds as Jesus bides his time before departing (7.34-6). On the last day of the festival, Jesus cries out once more and invites people to believe and become a source of living water $(7 \cdot 37-9) .^{86}$

81 For the figure of the Autogenes, see e.g. Ap. John NHC II 1 6.10-32; Gos. Eg. NHC III 2 65.5; Irenaeus, Haer. 1.29.2.

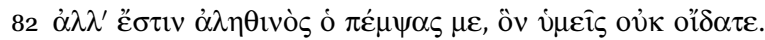

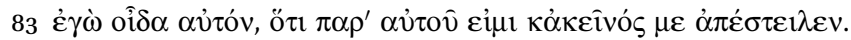

84 For the former: $1.1,14 ; 5.20,26$, 43; for the latter: $3.16-17,34 ; 5.23-4,30,37-8$.

85 As Lindars, Gospel, 293 puts it: 'As usual, there is an irony here: the people know where he comes from in the literal sense, but his real origin goes unrecognized; hence Jesus does pass the test [sc. that the origin of the Messiah be unknown].'

86 The theme of course is an important one at other key points in the gospel. Cf. 4.14 and 19.34. In general, see L. P. Jones, The Symbol of Water in the Gospel of John (JSNTSup 145; Sheffield: Sheffield Academic, 1997); D. Allison, 'The Living Water (John 4:10-14; 6:35c; 7:37-39)', St. Vladimir's Theological Quarterly 30 (1986) 143-57; M. J. J. Menken, 'The Origin of the Old Testament Quotation in John 7:38', NovT 38 (1996) 160-75; W.-Y. Ng, Water Symbolism 
The evangelist is not done with the issue of Jesus' origins. Jesus' invitation leads to more contention (7.40-3). Some respond thinking that he is 'the prophet'; others 'the Christ'. Then at 7.41 they ask, 'The scripture does not say that the Messiah will come from Galilee, does it? ${ }^{87}$ The question confirms what the reader suspected, but what was not made explicit in v. 27, that the crowd believes that Jesus came from Galilee. But, birthers that they are, they pose another question implying that a Galilean origin disqualifies Jesus from Messianic status. Their new question, unlike the first, expects a positive answer: 'Does not Scripture say that he [the Messiah] must be of the lineage of David and be from David's village, Bethlehem?' (7.42). ${ }^{88}$

Two claims thus are supposed to have a scriptural foundation. The crowd could have cited many texts to support the Messiah's Davidic descent. ${ }^{89}$ The key issue, however, is the second claim, the place of the Messiah's origin. The crowd no doubt found its information on this point in the text cited by Matthew, Mic 5.1. Had the evangelist read Matthew or was he, and the crowd, simply familiar with a Jewish Messianic interpretation of the prophet? We may never know, though I suspect that Matthew was indeed on the evangelist's horizon. ${ }^{90}$

In any case, there was, says the narrator (v. 43), a 'division' ( $\sigma \chi i \sigma \mu \alpha)$ in the crowd, as there has been in the interpretative tradition. Various readings of the episode's literary dynamics are possible. Which way one chooses largely depends on the way in which one sees the evangelist playing with intertexts.

The first possibility is that the evangelist thinks that the tradition represented by Mark is correct. Jesus was a Galilean. The crowd, by assuming that the Messiah had to be born in Bethlehem, on the basis of Mic 5.1, showed their ignorance, on a natural level, of the origins of Jesus. Their factual ignorance matched the spiritual ignorance or blindness displayed in their unwillingness to admit Jesus' claims about his heavenly origin.

The second possibility is that the evangelist thinks that the tradition represented by Matthew and Luke is correct. The crowd was then wrong to assume

in John: An Eschatological Interpretation (Studies in Biblical Literature 15; New York: Lang, 2001).

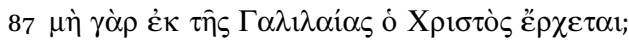

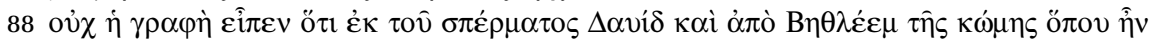

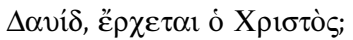

89 E.g. 2 Sam 7.12-13; 22.51; Ps 18.50; Isa 11.1; Jer 33.15; Ps 89(LXX 88).4-5; Pss. Sol. 17.4.

90 For John's possible use of Matthew, see G. van Belle and D. R. M. Godecharle, 'C.H. Dodd on John 13:16 (and 15:20): St. John's knowledge of Matthew revisited', Engaging with C. H. Dodd on the Gospel of John: Sixty Years of Tradition and Interpretation (ed. T. Thatcher and C. H. Williams; Cambridge: Cambridge University Press, 2013) 86-106; J. W. Barker, John's Use of Matthew (Minneapolis: Fortress, 2015). 
that Jesus was a Galilean. Their assumption that the Messiah had to be born in Bethlehem, on the basis of Mic 5.1, was correct, but their unwillingness to entertain the possibility that the prophetic text was fulfilled in Jesus, again, showed their ignorance, on a natural level, of his origins. Their factual ignorance matched the spiritual ignorance or blindness displayed in their unwillingness to admit Jesus' claims about his heavenly origin.

Another unlikely alternative reconciles the two options by finding a 'Bethlehem' in Galilee. Bruce Chilton has proposed such a solution, focusing on the city of Bet Lahm about $10 \mathrm{~km}$ west of Nazareth in the territory of the tribe of Zebulon (Jos 19.15). ${ }^{91}$ But that would not, of course, be a city of David.

Some commentators defend the first possibility and see the evangelist defending Jesus' Galilean origin, ${ }^{92}$ whether or not that tradition was historically accurate. ${ }^{93}$ Other commentators find it highly unlikely that the evangelist is unaware of the Bethlehem tradition, ${ }^{94}$ and, defending the second position, ${ }^{95}$ see elaborate

91 B. Chilton, 'Mamzerut and Jesus', Jesus from Judaism to Christianity: Continuum Approaches to the Historical Jesus (ed. T. Holmen; LNTS 352; London: T\&T Clark, 2007) 17-33, esp. 30-2. 92 Heil, 'Nazareth', 119-25 notes those who see John either ignorant of or rejecting the Bethlehem tradition, including: Bultmann, Gospel, 231; J. Becker, Das Evangelium des Johannes (2 vols.; ÖTKNT 4,1-2; Gütersloh: Mohn/Würzburg: Echter, 1991²) I.328-9; K. Wengst, Das Johannesevangelium. I. Teilband: Kapitel 1-10 (ThKNT 4/1; Stuttgart: Kohlhammer, 2001-4 ${ }^{2}$ ) I.296. Heil himself ('Nazareth', 130) reads the gospel as supporting an earthly origin of Jesus in Galilee.

93 Lindars, Gospel, 302-3 finds more evidence of this belief in the citation of Isa 9.1 in Matt 4.15, which he takes to be an attempt to defend a Galilean origin for Jesus, although Matthew himself clearly finds scriptural warrant for Bethlehem as Jesus' birthplace.

94 Heil, 'Nazareth', 120 cites C. Dietzfelbinger, Das Evangelium nach Johannes, I. Teilband: Johannes 1-12; II. Teilband: Johannes 13-21 (ZBK4.1-2; Zürich: Theologischer Verlag, 2001) I.227 and W. Radl, Der Ursprung Jesu: Traditionsgeschichtliche Untersuchungen zu Lukas 1-2 (Herders Biblische Studien 7; Freiburg i. Br., 1996) 365, n. 2. Heil, 'Nazareth', 121, n. 49 notes with U. Wilckens, Das Evangelium nach Johannes (NTD 4; Göttingen: Vandenhoeck \& Ruprecht, 1998; $2000^{2}$ ) 136 that knowledge of a Bethlehem tradition may only represent a Jewish expectation, not the stories told in Matthew and Luke.

95 Brown, Gospel, I.330; yet as Heil, 'Nazareth', 122, n. 57 observes, Brown is less certain of the evangelist's acquaintance with the tradition of Jesus' birth in Bethlehem in his Birth of the Messiah (New York: Doubleday, 1977) 516, n. 6. See also H. Thyen, 'Ich bin das Licht der Welt: Das Ich- und Ich-Bin-Sagen Jesu im Johannesevangelium', idem, Studien zum Corpus Johanneum (WUNT II/214; Tübingen: Mohr Siebeck, 2007) 213-51, esp. 233, and idem, Johannesevangelium, 409-10. See also C. S. Keener, The Gospel of John: A Commentary (2 vols.; Peabody, MA: Hendrickson, 2003) I.730: 'In contrast to Jesus' hearers in the story world, the informed reader probably knows that Jesus did after all come from Bethlehem (7:42), casting the hearers' skepticism in an ironic light'; he cites as favouring this reading (n. 265) J. Painter, John: Witness and Theologian (London: SPCK, 1975; 3rd edn: Micham, Victoria, Australia: Beacon Hill, 1986) 72-3; F. F. Bruce, The Time is Fulfilled (Grand Rapids: Eerdmans, 1979) 41; P. F. Ellis, The Genius of John: A Composition-Critical Commentary on the Fourth Gospel (Collegeville, MN: Liturgical Press, 1984) 8; P. D. Duke, Irony in the Fourth Gospel (Atlanta: John Knox, 1985) 67; H. N. Ridderbos, The Gospel according to John: 
irony at work. Through the ignorance of his characters the evangelist reveals important truths. ${ }^{96}$

What is a reader to make of the ambiguity, particularly if the reader is familiar with other gospels, as Richard Bauckham argues ${ }^{97}$ One might, like Schnackenburg, remain undecided.$^{98}$ Or perhaps, one might wonder whether the carefully structured ambiguity is itself a psychagogic device. When learned and insightful commentators divide so dramatically as they do on this point; when scholars of all stripes are hung to dry on a crux interpretum, it is time to reflect on the ironic narrative rhetoric of this text.

Bauckham is probably right on the general principle: the evangelist knows the Synoptics and presumes awareness of what other gospels say about Jesus in his narrative, although he also feels quite free to adapt and use synoptic material as suits his purpose. Wherever it came from, John 7.40-2 probably does exhibit knowledge not simply of Jewish expectations, but of the claim about Jesus made in Matthew and Luke that Jesus was born in Bethlehem. The prologue signals concern with the issue of where Jesus was from in commenting that his own 'did not receive him' (1.11). The tale of his rejection by Judaeans, from whom salvation is supposed to come (4.22), is particularly poignant. The plot describing that rejection reaches a preliminary climax at the end of the Feast of Tabernacles, although the rejection will become even more pronounced in what follows. Wherever Jesus was originally from, his rejection in Judaea is significant. The Ioudaioi were 'his own', but is that because he was 'from' Judaea? Perhaps, but can we be sure?

The irony is indeed complex. The crowd is hopelessly confused about where Jesus is from. But the dialogue in this chapter does not enable the reader to discern definitely which of the competing traditions is correct. In the interaction of the text and its (implied) reader an ironic play on knowledge and ignorance is at work. That play sheds light on the ambiguity encountered at the end of chapter 4. The fact that Jesus, 'a prophet', as some Jerusalemites now describe him (7.40), is rejected in Judaea could lie behind the ambiguous application of the proverb

A Theological Commentary (trans. J. Vriend; Grand Rapids/Cambridge: Eerdmans, 1997; English trans. of Het Evangelie naar Johannes: Proeve van een theologische Exegese (Kampen: Kok, 1992)) 277.

96 Heil, 'Nazareth', 122, citing B. H. Streeter, The Four Gospels: A Study of Origins. Treating of the Manuscript Tradition, Sources, Authorship and Dates (London: Macmillan, 1953 ${ }^{8}$ ) 407; L. Hurtado, Lord Jesus Christ: Devotion to Jesus in Earliest Christianity (Grand Rapids: Eerdmans, 2003) 360.

97 R. Bauckham, The Gospels for All Christians: Rethinking the Gospel Audiences (Grand Rapids: Eerdmans, 1998).

98 R. Schnackenburg, Das Johannesevangelium (4 vols.; HThKNT 4,1-4; Freiburg: Herder, 196584; English trans.: Smyth, Gospel), II.220. 
about dishonoured prophets in 4.44 . But in chapter 7 Jesus is rejected by his Galilean brothers as much as by the fickle Judaean crowds. The interplay between the earlier saying and the elaborate irony of this chapter suggests that the insertion of the saying in chapter 4 is not a blunder but part of a larger narrative strategy, a strategy designed to force the reader to question assumptions.

The evangelist knows a tradition, probably from Matthew and Luke, that the birth of Jesus took place in Judaea, and uses it to good effect in developing the theme of Jesus' origins. But, at the end of the day, he does not positively confirm that tradition. He does not provide a clear and definitive answer to the question of where the earthly Jesus is from. Instead, he invites readers who approach his gospel either with Markan or Matthean/Lukan presuppositions to put themselves in the position of the crowds in Jerusalem. He asks, 'By embracing one or another claim about Jesus' physical origin are you, like the people in the Temple, missing the basic point?' The historical fact does not, at the end of the day, matter. What counts is to recognise that Jesus was sent by the Father. His homeland, his Fatherland, his $\pi \alpha \tau \rho i \varsigma$, is his Father's heavenly abode, which, in another twist of Johannine irony, will become available on earth (14.23). The evangelist in effect says, recognising what you don't know, O Reader, can be the first step on the path to knowing something vitally important.

\section{Conclusion}

The evangelist wants his readers to know Jesus and the liberating Truth that he brings, but the narrative he creates assumes that coming to that knowledge can be a process that first involves an encounter with the unknown, the uncertain, an encounter that may baffle but also enthrals. Like Paul's appeal to an inscription 'to the unknown god' as a pedagogic device, it is worth noting that John too plays on the unknown as a step on the way to the Truth. 